\title{
Christian Pastors and Child Witches in Kinshasa, DRC
}

\author{
Nzash U. Lumeya
}

The article by Robert Priest, Abel Ngolo and Timothy Stabell (2020) on Christian pastors and children accused of witchcraft in Kinshasa, Democratic Republic of Congo, is a very well documented research paper. It sheds a bright light on the issue of family brokenness in some local families. Priest et al. have gathered a substantial amount of helpful data on witchcraft. It is informative and effective in raising the issue. It does not pretend to be a panacea but a sensitive and didactic instrument toward a constructive conversation regarding powerless children in Kinshasa.

Their bibliography, field research, interviews, and comparative and quantitative data all appropriately inspire readers to join this multidisciplinary conversation. The series of didactic tables distinguishes between terms such as "Kinshasa pastors, Christian pastors or church/churches". Thus, one understands that "Kinshasa pastors and churches" is limited to the 713 Kinshasa pastors that responded to the questionnaire. Table 3.1 .4 on page 18 reveals the church traditions of these Kinshasa Christian leaders. Priest, Ngolo and Stabell state that, "While it is likely that Kinshasa pastors share many of the same ideas about witches as others in their community, they nonetheless serve as influential authorities and thought leaders who affirm, formulate, and propagate the mix of ideas about witchcraft that is present in Kinshasa”(37). According to the authors, "it is in these Kinshasa churches, not in Muslim mosques, where allegations of child-witchcraft proliferate and flourish" (38). So, Priest et al. affirm that many of these Kinshasa pastors teach people to attribute the misfortunes in their lives to witches, including child witches.

I think that this Kinshasa cultural mind set needs transformation. This change in the way of coping with the cause of misfortune could learn from Congolese tradition and Jesus' teachings. Both advocate for community listening. When someone is accused of wrong doing, the wise judge could include a given community during the hearing and the deliberation. Their input could assist decision makers to reach a just and compassionate verdict.

\section{From Individualistic to Community-Based Hermeneutic}

The Congolese traditional extended family is hospitable and very relational. When a member suffers, the community participates in solving a given problem. Witch accusation does not escape the extended family's evaluation. Female and male mentors examine the accusations and make their respective recommenddations. Most of the time these recommendations seek for relational and peaceful, harmonious solutions. When someone is accused of witchcraft, the elder calls on family members to participate in the decision making process, because in this culture affection is more than effectiveness. In the case of a child offender, a compassionate member within the extended family will volunteer to take care of him/her. Since these mentors belong to the same extended family, they will address the offense in a way that mends the relationship and corrects the unacceptable behavior of a child. Belonging matters more than misconduct. As a result, these traditional villages don't have homeless children.

\section{Kinshasa Pastors and Children}

For more than two decades, I have been serving our Lord Jesus in Kinshasa as a local church pastor, overseer of 30 Mennonite Brethren local churches, and mission instructor. Our pastoral experience has taught us humility. The same way that Jesus, the great Shepherd or Pastor, received children, is the same way we are receiving children including those accused of practicing witchcraft. The mind of Christ has allowed many pastors to humble themselves to take care of the least of these. Some pastors have adopted children and put them back to school; others are asking the extended family to identify a host mentoring family for their accused child. Once found, the local church comes alongside this child within the context of a given affectionate nuclear or extended family. These new settings provide them with Christ-centered mentors. 
These humble ways of tackling the problem of a child accused of witchcraft invite the accusers to participate in repairing the relationship with the accused child. Pastors and the local fellowship of believers listen to the Holy Spirit as they guide broken families in the way of restored relationship. The Bible enlightens this path. Obedience to Jesus as our suffering Servant enables pastors to propagate the message of forgiveness. Jesus loves children. When they are accused of witchcraft, Kinshasa pastors could incorporate Jesus' way of getting the community involved in a peaceful resolution. Jesus came to save them also from their sins. Repentance is core for the transformation of our way of life. God taught us to follow him in letting him mend broken relationships and strengthen his Kingdom. There is hope in Jesus. The letter to the Hebrews reminds the people of Jesus in Kinshasa, "Since the children have flesh and blood, Jesus too shared in their humanity so that by his death he might destroy him who holds the power of death-that is, the devil-and free those who all their lives were held in slavery by their fear of death" (Hebrews 2:14-15).

\section{References}

Bible, the New International Version, Zondervan (1985).

Priest, Robert J., Abel Ngolo and Timothy Stabell. 2020. Christian Pastors and Alleged Child Witches in Kinshasa, DRC. On Knowing Humanity Journal 4(1):1-51.

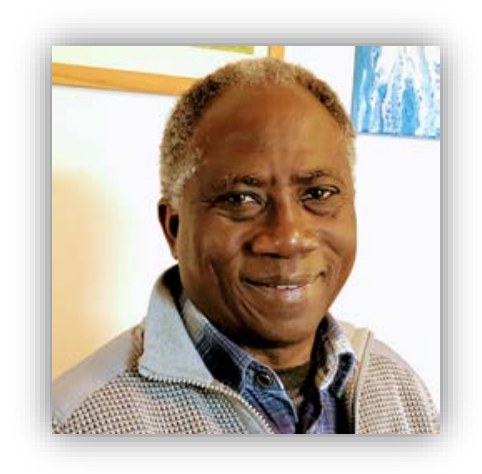

Nzash U Lumeya has a Ph.D. in Missiology from Fuller Seminary (1988) and a Master's in Theology from Faculte de Theologie Evangelique de Vaux-SurSeine, France (1977). He was Chaplain at the University of Kinshasa, Zaire, 1977-79, and then Assistant Professor at Bangui Evangelical School of Theology, 1979-82 and 1988-90. In 1991-1995 he was Assistant General Secretary of the Mennonite Brethren Church in Kinshasa, Zaire/DRC. In 19902000 he was Founder and of the Missiology School in Kinshasa, DRC, and in 1990-2000 he was Professor of Missiology at Missiology School in Kinshasa. In 2000-2005 he has been Assistant Professor at Mennonite Brethren Biblical Seminary in Fresno, California, USA. In 2005-2020 he was President of Fresno School of Mission and Visiting Professor of Missiology in Kinshasa. He is married to Christina Lumeya.

Author email: nlumeva@gmail.com 